\title{
EDITORIAL
}

\section{Idiopathic pulmonary fibrosis: present understanding and future options}

\author{
R.M. du Bois
}

$\mathbf{T}$ he past decade has been extraordinarily fruitful for the study and management of idiopathic pulmonary fibrosis (IPF). The ability of physicians to make a clear and definitive diagnosis has greatly improved, and a proliferation of clinical studies has started to build an evidence base upon which rational treatment decisions can be built. Nevertheless, the challenges facing patients and physicians remain formidable. The number of people dying from pulmonary fibrosis in the USA has increased by $50 \%$ in just 10 yrs (1992-2003) (fig. 1). The 175,088 deaths in such a short period highlight the devastating nature of this attritional lung disease, putting it on a par with many cancers in terms of outcome [1, 2].

The progression of IPF over time is characterised by repeated, focal episodes of epithelial cell perturbation and subsequent established fibrosis occurring over many years, resulting in a pattern of histopathology that is both temporally and spatially heterogeneous. Because of the repeated epithelial cell perturbation over time, much of the pathology consists of fixed fibrosis when the patient first presents requesting advice, with relatively little pathology that is amenable to improvement in response to any therapy. The nature of the disease process, and the likely response to treatment, therefore, means that we must be careful to set limits on expectations (for physicians and patients alike) of what any treatment can achieve. Since cure is currently impossible, the treatment goal should be to stabilise the disease if possible or at the least reduce the rate of progression. The new treatments needed to meet this treatment goal are now starting to emerge after a decade of unprecedented research activity, with significant and highly encouraging increases in the size and number of clinical studies and with the incremental increase in knowledge about the behaviour of the disease that has been gained over the past decade. In this regard, in the period of 1989-1999 a total of 114 patients were enrolled in four IPF studies [3-6], whereas the following decade (2000-2010) saw almost 3,000 patients enrolled in 11 studies (fig. 2) [7-16].

With this background of realistic expectations coupled with increasing optimism for IPF, a series of articles has reviewed the

CORRESPONDENCE: R.M. du Bois, Imperial College London, London, SW7 2AZ, UK. E-mail: ron@du-bois.co.uk

PROVENANCE: Publication of this peer-reviewed article was supported by InterMune Inc., Brisbane, CA, USA (article sponsor, European Respiratory Review issue 121).

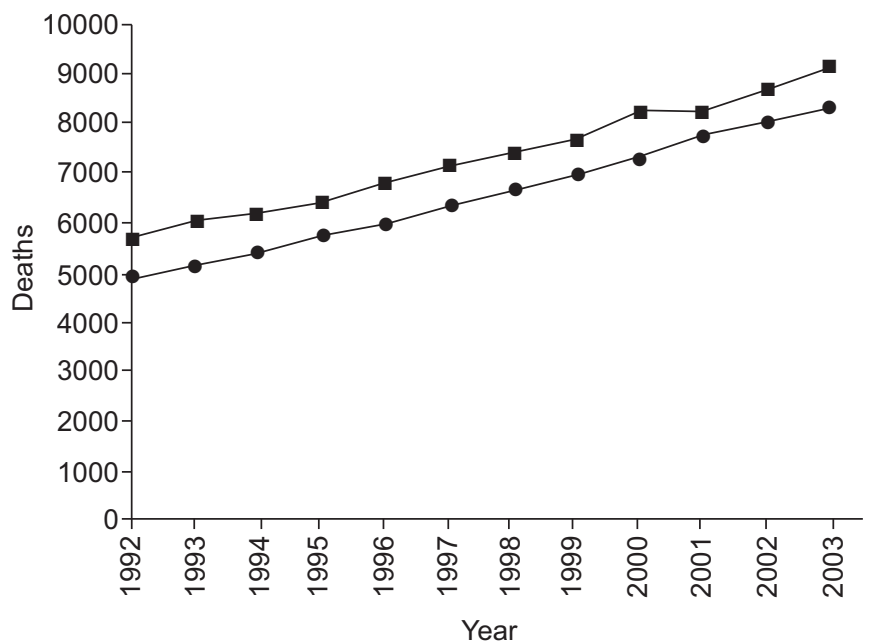

FIGURE 1. Mortality rates for pulmonary fibrosis significantly increased in the USA between 1992 and 2003 [1]. $\mathbf{\square}$ : males; $\bullet$ : females.

substantial progress that has been made in the management of IPF, and asked what advances we can reasonably expect in the coming years. VALEYRE [17] discussed the latest insights on diagnosis of IPF. ALBERA [18] considered which end-points are most useful for evaluating the efficacy of IPF treatments, while COSTABEL [19] provided an overview of the evaluation of clinical study data in IPF. Finally, EGAN [20] reviewed some of the strategies that are to be considered when drug therapy is no longer of value. Their expert contributions indicate that there is room for cautious optimism in this difficult therapeutic area, and that we may be entering an era in which prevention of progression is a reasonable goal for drug therapy.

\section{STATEMENT OF INTEREST}

R.M. du Bois has received reimbursement for attending the symposium, and fees for speaking and consultancy.

\section{ACKNOWLEDGEMENTS}

This article is based on the proceedings of a satellite symposium held at the 2010 ERS Annual Congress (Barcelona, Spain), which was sponsored by InterMune Inc. The author was assisted in the preparation of the text by professional medical writers at IntraMed International (Milan, Italy). The medical writing support was funded by InterMune Inc. 


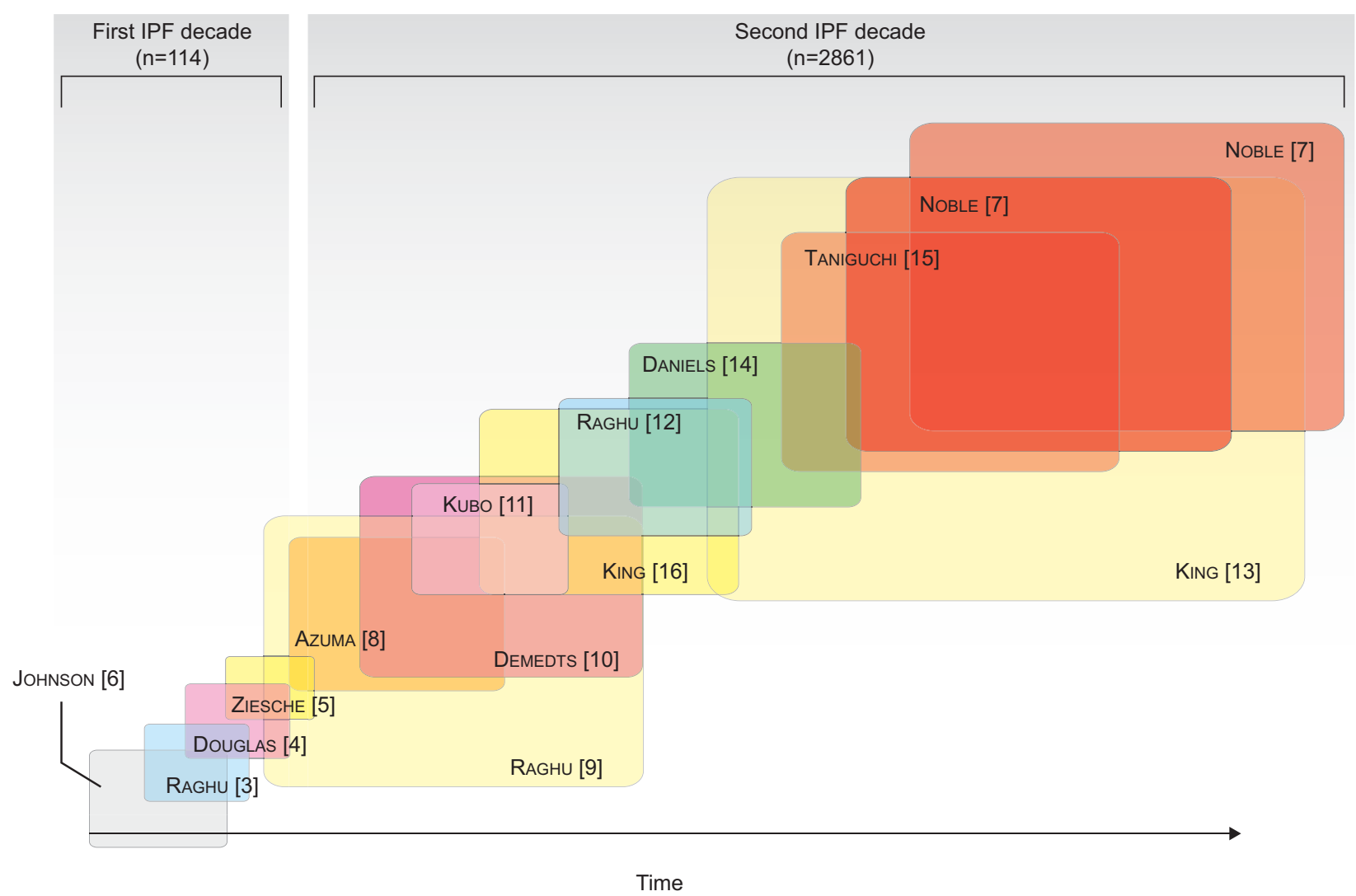

FIGURE 2. The number of patients enrolled in clinical studies of idiopathic pulmonary fibrosis (IPF) has increased substantially in the past decade compared to the previous decade [3-16]. Figure provided courtesy of L. Richeldi (University Modena and Reggio Emilia, Modena, Italy; personal communication).

\section{REFERENCES}

1 Olson AL, Swigris JJ, Lezotte DC, et al. Mortality from pulmonary fibrosis increased in the United States from 1992 to 2003. Am J Respir Crit Care Med 2007; 176: 277-284.

2 Altekruse SF, Kosary CL, Krapcho M, et al. SEER Cancer Statistics Review, 1975-2007. Bethesda, National Cancer Institute 2011. http://seer.cancer.gov/csr/1975_2007

3 Raghu G, Depaso WJ, Cain K, et al. Azathioprine combined with prednisone in the treatment of idiopathic pulmonary fibrosis: a prospective double-blind, randomized, placebo-controlled clinical trial. Am Rev Respir Dis 1991; 144: 291-296.

4 Douglas WW, Ryu JH, Swensen SJ, et al. Colchicine versus prednisone in the treatment of idiopathic pulmonary fibrosis. A randomized prospective study. Members of the Lung Study Group. Am J Respir Crit Care Med 1998; 158: 220-225.

5 Ziesche R, Hofbauer E, Wittmann K, et al. A preliminary study of long-term treatment with interferon $\gamma-1 \mathrm{~b}$ and low-dose prednisolone in patients with idiopathic pulmonary fibrosis. $N$ Engl J Med 1999; 341: 1264-1269.

6 Johnson MA, Kwan S, Snell NJ, et al. Randomised controlled trial comparing prednisolone alone with cyclophosphamide and low dose prednisolone in combination in cryptogenic fibrosing alveolitis. Thorax 1989; 44: 280-288.

7 Noble PW, Albera C, Bradford W, et al. Pirfenidone in patients with idiopathic pulmonary fibrosis (CAPACITY: two randomised trials). Lancet 2011; 377: 1760-1769.

8 Azuma A, Nukiwa T, Tsuboi E, et al. Double-blind, placebocontrolled trial of pirfenidone in patients with idiopathic pulmonary fibrosis. Am J Respir Crit Care Med 2005; 171: 1040-1047.
9 Raghu G, Brown KK, Bradford WZ, et al. A placebo-controlled trial of interferon $\gamma-1 \mathrm{~b}$ in patients with idiopathic pulmonary fibrosis. N Engl J Med 2004; 350: 125-133.

10 Demedts M, Behr J, Buhl R, et al. High-dose acetylcysteine in idiopathic pulmonary fibrosis. N Engl J Med 2005; 353: 2229-2242.

11 Kubo H, Nakayama K, Yanai M, et al. Anticoagulant therapy for idiopathic pulmonary fibrosis. Chest 2005; 128: 1475-1482.

12 Raghu G, Brown KK, Costabel U, et al. Treatment of idiopathic pulmonary fibrosis with etanercept: an exploratory, placebocontrolled trial. Am J Respir Crit Care Med 2008; 178: 948-955.

13 King TE Jr, Albera C, Bradford WZ, et al. Effect of interferon $\gamma-1 b$ on survival in patients with idiopathic pulmonary fibrosis (INSPIRE): a multicentre, randomised, placebo-controlled trial. Lancet 2009; 374: 222-228.

14 Daniels CE, Lasky JA, Limper $\mathrm{AH}$, et al. Imatinib treatment for idiopathic pulmonary fibrosis: randomized placebo-controlled trial results. Am J Respir Crit Care Med 2010; 181: 604-610.

15 Taniguchi H, Ebina M, Kondoh Y, et al. Pirfenidone in idiopathic pulmonary fibrosis. Eur Respir J 2010; 35: 821-829.

16 King TE Jr, Behr J, Brown KK, et al. BUILD-1: a randomized placebo-controlled trial of bosentan in idiopathic pulmonary fibrosis. Am J Respir Crit Care Med 2008; 177: 75-81.

17 Valeyre D. Towards a better diagnosis of idiopathic pulmonary fibrosis. Eur Respir Rev 2011; 20: 108-113.

18 Albera C. Challenges in idiopathic pulmonary fibrosis: the points on end-points. Eur Respir Rev 2011; 20: 195-200.

19 Costabel U. Emerging potential treatments: new hope for idiopathic pulmonary fibrosis patients? Eur Respir Rev 2011; 20: 201-207.

20 Egan J. Follow-up and non-pharmacological management of the idiopathic pulmonary fibrosis patient. Eur Respir Rev 2011; 20: 114-117. 